\title{
Photochemistry of Methane in the Photoionization Region*
}

\author{
R. E. Rebbert and P. Ausloos
}

Institute for Materials Research, National Bureau of Standards, Washington, D.C. 20234

(October 4, 1972)

\begin{abstract}
Methane was irradiated with microwave operated helium $(21.2 \mathrm{eV})$ and neon $(16.7-16.8 \mathrm{eV})$ resonance lamps which were separated from the reaction vessel by an aluminum window. The quantum yields of the stable end products have been determined at methane pressures ranging from 1 to 20 torr. Over this pressure range the abundances of the primary ions, determined through various diagnostic experiments, are within experimental error the same at $21.2 \mathrm{eV}$ as at $16.7-16.8 \mathrm{eV} !\left(\mathrm{CH}_{4}^{+} \simeq \mathrm{CH}_{3}^{+} \simeq\right.$ $0.5, \mathrm{CH}_{2}^{+} \leqslant 0.02$ ), and are in good agreement with the primary mass spectra obtained in a photoionization mass spectrometer under collision free conditions $\left(P<10^{-5}\right.$ torr $)$. The $\mathrm{C}_{2} \mathrm{H}_{5}^{+}$which is formed by the reaction: $\mathrm{CH}_{3}^{+}+\mathrm{CH}_{4} \rightarrow \mathrm{C}_{2} \mathrm{H}_{5}^{+}+\mathrm{H}_{2}$ loses a proton by an undetermined mechanism to give $\mathrm{C}_{2} \mathrm{H}_{4}$ as a product.

There is no evidence for the formation of neutral fragments such as $\mathrm{H}_{2}, \mathrm{C}, \mathrm{CH}$ or $\mathrm{CH}_{2}$ at 16.7$1.6 .8 \mathrm{eV}$. The fact that the ionization quantum is equal to unity in this energy range accounts for the absence of these intermediates. At $21.2 \mathrm{eV}$ where $\left(\Phi_{\text {ionization }}=0.95\right)$ there is concrete evidence for the formation of carbon atoms $(\Phi(C) \geqslant 0.002)$.

In an attempt to demonstrate the usefulness of enclosed neon and helium resonance light sources in the ion-molecule kinetic studies, the relative probabilities of transfer of $\mathrm{H}^{-}$over $\mathrm{D}^{-}$from various partially deuterium labeled hydrocarbons to $\mathrm{C}_{2} \mathrm{H}_{5}^{+}$(or $\mathrm{C}_{2} \mathrm{D}_{5}^{+}$) has been determined.

The results presented in this article resolve the existing disagreements between previous helium resonance photolysis studies on $\mathrm{CH}_{4}$.
\end{abstract}

Key words: Ion-molecule reaction; ion pair yield; methane; photochemistry; photoionization; quantum yields.

\section{Introduction}

In a pioneering study, Back and Walker $[1]^{1}$ carried out the first photochemistry study on lower hydrocarbons in the photoionization region using the selfreversed $58.4 \mathrm{~nm}(21.2 \mathrm{eV})$ helium resonance line. The apparatus used was windowless and the photolysis vessel was separated from the light source (microwave discharge through helium) by a fast flow separation system. Significant experimental results were obtained even though such an open device limited the reactant pressure range in the reaction vessel $(<0.3$ torr $)$ and resulted in a certain degree of uncertainty concerning the monochromaticity of the incident radiation. More recently, thin (1500 to $4000 \AA$ thick) alurninum films supported on a metal screen have been used to separate the light source from the reaction vessel and to

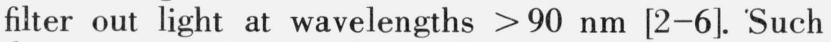
devices were first used in 1968 to reexamine certain aspects of the photolysis of methane at $58.4 \mathrm{~nm}$ at reactant pressures up to 15 torr.

The present paper describes a more detailed study of the photochemistry of $\mathrm{CH}_{4}$ in the photoionization region using an enclosed helium as well as a neon

${ }^{*}$ Sponsored in part by the U.S. Atomic Energy Commission.

${ }^{1}$ Figures in brackets indicate the literature references at the end of this paper. resonance $(\lambda=74.37-73.59 \mathrm{~nm})$ light source. An attempt is made to resolve the existing disagreements in the yields of the chemical products formed in the windowless apparatus used by Back and Walker [1] as compared to the enclosed light source apparatus employed by Jensen and Libby [2]. Finally, reactions of the major ions, $\mathrm{CH}_{5}^{+}$and $\mathrm{C}_{2} \mathrm{H}_{5}^{+}$, formed in the photoionization of methane with various hydrocarbons are explored in order to assess the feasibility of using enclosed helium and neon resonance light sources in the study of ionic reactions.

\section{Experimental Procedure}

\subsection{Apparatus}

The design of the titanium-gettered light sources and of the reaction vessel has been described in a recent report from this laboratory [7]. The aluminum windows (0.61 in in diameter) were supplied by the Sigmatron Co., Goleta, California [8]. They consisted of a $1500 \pm$ $100 \AA$ film supported on a nickel screen. The windows were examined for pin-holes under a microscope and were tested for their pressure resistance. The approximately 50 photolysis experiments carried out in the course of this investigation at differential pressure readings up to 60 torr, were carried out by using one and the same enclosed light source. Transformation 
of the helium lamp to a neon resonance light source, and vice versa, was accomplished by interchanging the rare gases in the body of the enclosed lamp. The pressure in the helium lamp was 1.6 torr and that in the neon lamp was 1.2 torr. In a recent detailed examination [9] of the output of a helium resonance lamp it was shown that at a helium pressure of 1.2 to 2 torr the $53.7 \mathrm{~nm}$ line transmitted through a $1500 \AA$ window is approximately 2 percent of the intensity of the 58.4 $\mathrm{nm}$ line. The total output of the helium lamp used in this study was approximately $2 \times 10^{13}$ photons/s. The same lamp filled with neon had a light flux of $0.8 \times 10^{13}$ photons/s. The output of the lamp, which was monitored by measuring the saturation ion current in $\mathrm{CH}_{4}$ showed only very minor fluctuations ( 2 to $5 \%$ ) from one experiment to the next. The volume of the reaction vessel equipped with nickel electrodes was $220 \mathrm{~cm}^{3}$.

\subsection{Materials}

All chemicals used in this study were purified by gas chromatography. The methane- $d_{4}$ contained 5 percent $\mathrm{CD}_{3} \mathrm{H}$. The cyclohexane, $1,1,2,2,3,3-d_{6}$ sample used in some experiments contained 10.3 percent cyclohexane- $d_{5}, 2.4$ percent cyclohexane- $d_{7}$ and 0.3 percent cyclohexane- $d_{8}$. Propane-1,1,1,3,3,3- $d_{6}$ contained 6 percent $\mathrm{CD}_{2} \mathrm{HCH}_{2} \mathrm{CD}_{3}$ and 1.7 percent $\mathrm{CD}_{3} \mathrm{CHDCD}_{3}$. More than 93 percent of the isobutane- $d_{1}$ consisted of $\left(\mathrm{CH}_{3}\right)_{3} \mathrm{CD}$. The calculated isotopic compositions of the products reported in this paper have been corrected statistically to bring the data up to 100 percent deuterium purity.

\section{Results}

All product yields are expressed in terms of quantum yields $(\Phi)$. Because the ionization quantum yield of methane is close to unity in the wavelength region covered in this study [10-11], quantum yields are essentially equivalent to ion pair yields (number of product molecules per positively charged ion produced in the system). The absolute accuracy of the quantum yield values given in tables 1 and 2 are estimated to be \pm 15 percent. Besides the products listed in tables 1 and 2, hydrogen and several higher molecular weight hydrocarbon products such as $i-\mathrm{C}_{4} \mathrm{H}_{10}$ and $i-\mathrm{C}_{5} \mathrm{H}_{12}$ were observed. The quantum yields of $i-\mathrm{C}_{4} \mathrm{H}_{10}$ and $i-\mathrm{C}_{5} \mathrm{H}_{12}$ were seen to increase with the number of photons absorbed in the system and were therefore ascribed to secondary reactions involving accumulated products. The values of $\Phi\left(i-\mathrm{C}_{4} \mathrm{H}_{10}\right)$ and $\Phi\left(i-\mathrm{C}_{5} \mathrm{H}_{12}\right)$ for the lowest conversion experiment listed in table 1 were 0.003 and 0.002 respectively.

Hydrocarbon products with more than five carbon atoms were not observed at low conversions $(\Phi<$ 0.005 ). The quantum yield of hydrogen in the $58.4 \mathrm{~nm}$ photolysis of a $\mathrm{CH}_{4}-\mathrm{CD}_{4}$-NO (1:1:0.01) mixture at a pressure of 10 torr was $0.4 \pm 0.1$. Its isotopic composition was as follows: $\mathrm{H}_{2}-44.6$ percent, HD-26.5 percent, $\mathrm{D}_{2}-28.9$ percent. In the $58.4 \mathrm{~nm}$ photolysis of a $\mathrm{CH}_{4}-i$ $\mathrm{C}_{4} \mathrm{D}_{10}(1: 0.01)$ mixture at a pressure of 20 torr $\Phi$ (hydrogen) was $0.55 \pm 0.1$ and consisted of $\mathrm{H}_{2}-67.8$ percent, HD-16.7 percent and $D_{2}-15.5$ percent. Both hydrogen analysis experiments were carried out at relatively high conversion $\left(1.5 \times 10^{17}\right.$ photons absorbed by 10 torr of methane in the $220 \mathrm{~cm}^{3}$ reaction vessel). The isotopic composition of the ethylene produced in the $58.4 \mathrm{~nm}$ photolysis of the $\mathrm{CH}_{4}-\mathrm{CD}_{4}$ - $\mathrm{NO}(1: 1: 0.01) \mathrm{mix}$ ture is as follows: $\mathrm{C}_{2} \mathrm{D}_{4}-14$ percent, $\mathrm{C}_{2} \mathrm{D}_{3} \mathrm{H}-16$ percent, $\mathrm{C}_{2} \mathrm{D}_{2} \mathrm{H}_{2}-22$ percent, $\mathrm{C}_{2} \mathrm{DH}_{3}-16$ percent, $\mathrm{C}_{2} \mathrm{H}_{4}-32$ percent. Photolysis of an equimolar $\mathrm{CH}_{4}-\mathrm{CD}_{4}$ in the presence of 1 mole percent $i-\mathrm{C}_{4} \mathrm{H}_{10}$ yielded: $\mathrm{C}_{2} \mathrm{D}_{4}$ 16 percent, $\mathrm{C}_{2} \mathrm{D}_{3} \mathrm{H}-17$ percent, $\mathrm{C}_{2} \mathrm{D}_{2} \mathrm{H}_{2}-21.5$ percent, $\mathrm{C}_{2} \mathrm{DH}_{3}-13.5$ percent, and $\mathrm{C}_{2} \mathrm{H}_{4}-32$ percent.

The isotopic analysis of the ethane formed in the neon resonance photolysis of a $\mathrm{CD}_{4}-\mathrm{C}_{3} \mathrm{H}_{8}-\mathrm{O}_{2}(1: 0.01: 0.1)$ mixture at a total pressure of 20 torr, was as follows: $\mathrm{C}_{2} \mathrm{D}_{5} \mathrm{H}-47.2$ percent, $\mathrm{C}_{2} \mathrm{D}_{4} \mathrm{H}_{2}-0.5$ percent, and $\mathrm{C}_{2} \mathrm{H}_{6^{-}}$ 52.3 percent. The ethane formed in the helium and neon resonance photolysis of $\mathrm{CD}_{4}-i-\mathrm{C}_{4} \mathrm{H}_{10}-\mathrm{O}_{2}$ (1:0.01: 0.01 ) mixtures consisted nearly entirely ( $>97$ percent) of $\mathrm{C}_{2} \mathrm{D}_{5} \mathrm{H}$.

\section{Discussion}

\subsection{General Comments}

Recent determinations of the photoionization quantum yield $\left(\Phi_{+}\right)$of $\mathrm{CH}_{4}$ at $58.4 \mathrm{~nm}$ and at 74.37-73.59 $\mathrm{nm}$ indicate that approximately one ion pair is produced for each photon absorbed by methane [10-11]. It follows that in this wavelength region there is one predominant primary process

$$
\mathrm{CH}_{4}+h \nu \rightarrow\left(\mathrm{CH}_{4}^{+}\right)^{*}+e .
$$

The ion pair formation process

$$
\mathrm{CH}_{4}+h \nu \rightarrow \mathrm{CH}_{3}^{+}+\mathrm{H}^{-}
$$

is apparently of minor importance [12-13]. The helium and neon resonance photoelectron spectrum shows one broad band over the range 12.7 to $16-17 \mathrm{eV}$, exhibiting three maxima associated with the ionization of the $t_{2}$ orbital [14-15]. Besides the ionization potential at $12.7 \mathrm{eV}$, there is a second I.P. near $23 \mathrm{eV}$, ascribed to ionization from the $a_{1}$ orbital, which is however of no concern in this study. A fraction of the vibrationally excited $\left(\mathrm{CH}_{4}^{+}\right)^{*}$ formed in process 1 can dissociate to produce $\mathrm{CH}_{3}^{+}$(appearance potential $14.2 \mathrm{eV}$ ) and $\mathrm{CH}_{2}^{+}$ (appearance potential $15.2 \mathrm{eV}$ ) [12-13]

$$
\begin{aligned}
\left(\mathrm{CH}_{4}^{+}\right)^{*} & \rightarrow \mathrm{CH}_{3}^{+}+\mathrm{H} \\
& \rightarrow \mathrm{CH}_{2}^{+}+\mathrm{H}_{2} .
\end{aligned}
$$

The abundances of $\mathrm{CH}_{4}^{+}, \mathrm{CH}_{3}^{+}$, and $\mathrm{CH}_{2}^{+}$observed in a photoionization mass spectrometer [12] using an enclosed helium resonance lamp such as the one used in the present study are: $\mathrm{CH}_{4}^{+}-48$ percent, $\mathrm{CH}_{3}^{+}-50$ percent, and $\mathrm{CH}_{2}^{+}-2$ percent. The abundances observed with a neon resonance lamp are $\mathrm{CH}_{4}^{+}-47$ percent, $\mathrm{CH}_{3}^{+}-51$ percent and $\mathrm{CH}_{2}^{+}-2$ percent. It is to be noted that both distributions are at variance with the abundances obtained in previous photoionization mass spectrometric studies [13] in which a 
differentially pumped continuous light source was used.

The major initial bimolecular reactions occurring in the photoionization of $\mathrm{CH}_{4}$ are [16]

$$
\begin{aligned}
& \left(\mathrm{CH}_{4}^{+}\right)^{*}+\mathrm{CH}_{4} \rightarrow \mathrm{CH}_{5}^{+}+\mathrm{CH}_{3} \\
& \mathrm{CH}_{3}^{+}+\mathrm{CH}_{4} \rightarrow \mathrm{C}_{2} \mathrm{H}_{5}^{+}+\mathrm{H}_{2} \\
& \mathrm{CH}_{2}^{+}+\mathrm{CH}_{4} \rightarrow \mathrm{C}_{2} \mathrm{H}_{4}^{+}+\mathrm{H}_{2} .
\end{aligned}
$$

The product ions $\mathrm{CH}_{5}^{+}, \mathrm{C}_{2} \mathrm{H}_{5}^{+}$and $\mathrm{C}_{2} \mathrm{H}_{4}^{+}$are unreactive towards $\mathrm{CH}_{4}[16]$ and will therefore be converted to neutral products by heterogeneous or homogeneous neutralization or by proton transfer to traces of $\mathrm{H}_{2} \mathrm{O}$. At higher conversions these ions will react with accumulated products [17-19].

From the foregoing, one would expect $\mathrm{H}_{2}, \mathrm{C}_{2} \mathrm{H}_{6}$, and $\mathrm{C}_{2} \mathrm{H}_{4}$ to be major products in the far ultraviolet photolysis of "pure" methane. This is borne out by the data given in tables 1 and 2 as well as in the Results Section. Although there is essentially little to be learned from product yields such as the ones given in tables 1 and 2 for the "pure" $\mathrm{CH}_{4}$ system it is nevertheless of some interest to compare the product yields obtained in this study at $58.4 \mathrm{~nm}$ with those reported previously by other investigators [1-2] (table 1) and to interpret some of the observations in the light of the remarks made above.

\section{a. Effect of Conversion}

The fact that upon addition of $\mathrm{O}_{2}$ to $\mathrm{CH}_{4}, \Phi\left(\mathrm{C}_{2} \mathrm{H}_{6}\right)$ is reduced from approximately 0.3 to 0.01 at 58.4 and $74.3-73.6 \mathrm{~nm}$ indicates that $\mathrm{C}_{2} \mathrm{H}_{6}$ is produced mainly by a free radical reaction such as:

$$
\mathrm{CH}_{3}+\mathrm{CH}_{3} \rightarrow \mathrm{C}_{2} \mathrm{H}_{6} .
$$

The increase of $\Phi\left(\mathrm{C}_{3} \mathrm{H}_{8}\right)$ and $\Phi\left(n-\mathrm{C}_{4} \mathrm{H}_{10}\right)$ with an increase in the number of photons absorbed (tables 1 and 2) can be ascribed to $\mathrm{H}$-atom scavenging by the $\mathrm{C}_{2} \mathrm{H}_{4}$ product molecules

$$
\begin{gathered}
\mathrm{C}_{2} \mathrm{H}_{4}+\mathrm{H} \rightarrow \mathrm{C}_{2} \mathrm{H}_{5} \\
\mathrm{C}_{2} \mathrm{H}_{5}+\mathrm{CH}_{3} \rightarrow \mathrm{C}_{3} \mathrm{H}_{8} \\
\mathrm{C}_{2} \mathrm{H}_{5}+\mathrm{C}_{2} \mathrm{H}_{5} \rightarrow n-\mathrm{C}_{4} \mathrm{H}_{10} .
\end{gathered}
$$

This mechanism, which has previously [20] also been shown to occur in the $10 \mathrm{eV}$ photolysis of $\mathrm{CH}_{4}$, is corroborated by the fact that $\Phi\left(\mathrm{C}_{2} \mathrm{H}_{4}\right)$ diminishes at higher conversion and that $\Phi\left(\mathrm{C}_{3} \mathrm{H}_{8}\right)$ is sharply reduced upon addition of $\mathrm{O}_{2}$. The increase of $\Phi\left(\mathrm{C}_{2} \mathrm{H}_{6}\right)$ with the number of photons absorbed in the system can at least in part be ascribed to combination of the $\mathrm{C}_{2} \mathrm{H}_{5}$ radicals formed in reaction 9 with $\mathrm{H}$-atoms. It is clear however that at very high conversion the decrease in $\Phi\left(\mathrm{C}_{2} \mathrm{H}_{4}\right)$ is not entirely compensated by the increase of the quantum yields of $\mathrm{C}_{2} \mathrm{H}_{6}, \mathrm{C}_{3} \mathrm{H}_{8}$ and $n-\mathrm{C}_{4} \mathrm{H}_{10}$. Complex ion-molecule reaction chains initiated by the addi- tion of $\mathrm{C}_{2} \mathrm{H}_{5}^{+}$to $\mathrm{C}_{2} \mathrm{H}_{4}$ [19] may cause a further reduction in the quantum yield of $\mathrm{C}_{2} \mathrm{H}_{4}$. Although the conversion effects noted in this study could account for the low quantum for $\mathrm{C}_{2} \mathrm{H}_{4}$ reported by Jensen and Libby [2], they do not account for the extremely low quantum yield of $\mathrm{C}_{2} \mathrm{H}_{6}$ (table 1) reported by these authors. In view of the fact that the $\Phi\left(\mathrm{C}_{2} \mathrm{H}_{6}\right)$ is seen to be essentially reduced to zero by $\mathrm{O}_{2}$, it may be surmised that air contamination in the $\mathrm{CH}_{4}$ accounts for the observations of Jensen and Libby [2].

\section{b. Formation of Ethylene}

The ethylene originates apparently from the $\mathrm{C}_{2} \mathrm{H}_{5}^{+}$ ion formed in reaction 6. Addition of small amounts of isobutane to $\mathrm{CH}_{4}$ drastically reduces $\Phi\left(\mathrm{C}_{2} \mathrm{H}_{4}\right)$ both in the neon and helium resonance experiments (tables 1 and 2). This reduction which is accompanied by a corresponding increase of $\Phi\left(\mathrm{C}_{2} \mathrm{H}_{6}\right)$ in the presence or in the absence of $\mathrm{O}_{2}$ is to be accounted for [17] by the removal of the $\mathrm{C}_{2} \mathrm{H}_{5}^{+}$ion via the hydride ion transfer reaction

$$
\mathrm{C}_{2} \mathrm{H}_{5}^{+}+i-\mathrm{C}_{4} \mathrm{H}_{10} \rightarrow \mathrm{C}_{2} \mathrm{H}_{6}+\mathrm{C}_{4} \mathrm{H}_{9}^{+}
$$

Formation of $\mathrm{C}_{2} \mathrm{H}_{6}$ in reaction 12 is substantiated by the fact that more than 90 percent of the ethane formed in the photoionization of $\mathrm{CD}_{4}-i-\mathrm{C}_{4} \mathrm{H}_{10}-\mathrm{O}_{2}$ mixtures (see Results) consists of $\mathrm{C}_{2} \mathrm{D}_{5} \mathrm{H}$. Also, $\Phi\left(\mathrm{C}_{2} \mathrm{H}_{6}\right)$ is seen to be independent of the concentration of $i-\mathrm{C}_{4} \mathrm{H}_{10}$ (see table 1). Furthermore, it is to be noted that $\Phi\left(\mathrm{C}_{2} \mathrm{H}_{6}\right)$ is close to the value predicted from the abundance of $\mathrm{CH}_{3}^{+}$in the primary photoionization mass spectrum [12-13]. At these low concentration of $i-\mathrm{C}_{4} \mathrm{H}_{10}$, the reduction of the yield of $\mathrm{C}_{2} \mathrm{H}_{4}$ cannot be attributed to inhibition of the insertion reaction

$$
\mathrm{CH}+\mathrm{CH}_{4} \rightarrow \mathrm{C}_{2} \mathrm{H}_{4}+\mathrm{H}
$$

which was previously suggested [2] to be the main mode of formation of $\mathrm{C}_{2} \mathrm{H}_{4}$ in the $58.4 \mathrm{~nm}$ photolysis of "pure" $\mathrm{CH}_{4}$. It has indeed been shown recently [21] that $\mathrm{CH}$ reacts about equally fast with all lower alkanes. As noted before [22], the apparently low yield of $\mathrm{CH}$ species is consistent with the fact that dissociation of superexcited $\mathrm{CH}_{4}$ molecules is of minor occurrence at 58.4 and $74.3-73.6 \mathrm{~nm}$. Furthermore, the isotopic composition of the ethylene formed in the photoionization of $\mathrm{CH}_{4}-\mathrm{CD}_{4}$ and $\mathrm{CH}_{4}-\mathrm{CD}_{4}-i-\mathrm{C}_{4} \mathrm{H}_{10}$ mix tures (see Results) is not consistent with an insertion mechanism. In the $\mathrm{CH}_{4}$-alkane mixture given in tables 1 and $2, \Phi\left(\mathrm{C}_{2} \mathrm{H}_{6}\right)$ is approximately equal to the reduction in $\Phi\left(\mathrm{C}_{2} \mathrm{H}_{4}\right)$, indicating that in "pure" methane most of the $\mathrm{C}_{2} \mathrm{H}_{5}^{+}$ions yield $\mathrm{C}_{2} \mathrm{H}_{4}$ as a neutral product. Pulse radiolysis experiments [23] have shown that if the neutralization occurs by electron recombination, acetylene is produced through the following reaction sequence:

$$
\mathrm{C}_{2} \mathrm{H}_{5}^{+}+e \rightarrow \mathrm{C}_{2} \mathrm{H}_{5}^{*}
$$




$$
\begin{gathered}
\mathrm{C}_{2} \mathrm{H}_{5}^{*} \rightarrow \mathrm{C}_{2} \mathrm{H}_{4}^{*}+\mathrm{H} \\
\mathrm{C}_{2} \mathrm{H}_{4}^{*} \rightarrow \mathrm{C}_{2} \mathrm{H}_{2}+\mathrm{H}_{2} .
\end{gathered}
$$

Because at a methane pressure of 100 torr approximately 50 percent of the excited $\mathrm{C}_{2} \mathrm{H}_{4}$ formed in process 15 were shown to dissociate [23], the low yield of $\mathrm{C}_{2} \mathrm{H}_{2}$ in the photoionization experiments (tables 1 and 2) rules out reaction 14 as an important mode of neutralization of the $\mathrm{C}_{2} \mathrm{H}_{5}^{+}$ion. Proton transfer on the aluminum window surface and/or to $\mathrm{H}_{2} \mathrm{O}$ desorbed from the wall is a likely explanation for the nearly quantitative conversion of $\mathrm{C}_{2} \mathrm{H}_{5}^{+}$ions to $\mathrm{C}_{2} \mathrm{H}_{4}$. The fact that addition of a proton acceptor such as acetone to $\mathrm{CH}_{4}$ (table 2)

$$
\mathrm{C}_{2} \mathrm{H}_{5}^{+}+\mathrm{CH}_{3} \mathrm{COCH}_{3} \rightarrow \mathrm{C}_{2} \mathrm{H}_{4}+\mathrm{CH}_{3} \mathrm{COCH}_{4}^{+}
$$

does not significantly alter $\Phi\left(\mathrm{C}_{2} \mathrm{H}_{4}\right)$ observed in pure methane supports the above interpretation. It is of interest at this point to compare our data with those obtained by Walker and Back [1] in a windowless apparatus. It is seen (table 1) that with the exception of $\Phi\left(\mathrm{C}_{2} \mathrm{H}_{2}\right)$, the agreement between the two studies is excellent. Considering that Walker and Back [1] used a continuous $\mathrm{CH}_{4}$-He flow through a windowless reaction vessel, their high $\mathrm{C}_{2} \mathrm{H}_{2}$ yields are most likely to be attributed to gas phase neutralization (reaction sequence 14-16). The isotopic analysis of the ethylene obtained in the photolysis of a $\mathrm{CH}_{4}-\mathrm{CD}_{4}-i-\mathrm{C}_{4} \mathrm{H}_{10}$ mixture (see Results), indicates that the residual ethylene $(\Phi \sim 0.03)$ observed in the $\mathrm{CH}_{4}-i-\mathrm{C}_{4} \mathrm{H}_{10}$ experiments (tables 1 and 2) may be accounted for by ineffective scavenging of the $\mathrm{C}_{2} \mathrm{H}_{5}^{+}$ions by $i-\mathrm{C}_{4} \mathrm{H}_{10}$.

Unreactive ethylene ions formed in reaction 7 may conceivably also contribute to the formation of $\mathrm{C}_{2} \mathrm{H}_{4}$. However, the very low yield of $\mathrm{C}_{2} \mathrm{D}_{4} \mathrm{H}_{2}(\sim 0.005)$ observed in a $\mathrm{CD}_{4}-\mathrm{C}_{3} \mathrm{H}_{8} \quad(1: 0.01)$ experiment (see Results) carried out in the presence of $\mathrm{O}_{2}$ indicates that the well established ion-molecule reaction [24]:

$$
\mathrm{C}_{2} \mathrm{D}_{4}^{+}+\mathrm{C}_{3} \mathrm{H}_{8} \rightarrow \mathrm{C}_{2} \mathrm{D}_{4} \mathrm{H}_{2}+\mathrm{C}_{3} \mathrm{H}_{6}^{+}
$$

does not occur to any significant extent in such an experiment. Since approximately 50 percent of the $\mathrm{C}_{2} \mathrm{D}_{4}^{+}$ions would react through the competing reaction channel [25]:

$$
\mathrm{C}_{2} \mathrm{D}_{4}^{+}+\mathrm{C}_{3} \mathrm{H}_{8} \rightarrow \mathrm{C}_{2} \mathrm{D}_{4} \mathrm{H}+\mathrm{C}_{3} \mathrm{H}_{7}^{+}
$$

the quantum yield of $\mathrm{C}_{2} \mathrm{D}_{4}^{+}$is estimated to be about 0.01 . This low value is in excellent agreement with the value of 0.0093 for $\Phi\left(C D_{z}^{+}\right)$recently derived from the neon resonance photoionization mass spectrum of $\mathrm{CD}_{4}$ [12]. The value estimated here is, however, lower than that indicated by the primary mass spectrum of $\mathrm{CD}_{4}$ obtained in an earlier mass spectrometric photoionization study [13].

\section{c. Formation of Hydrogen}

The fact that at $58.4 \mathrm{~nm}$, the quantum yield of hydrogen observed in a $\mathrm{CH}_{4}-\mathrm{CD}_{4}-\mathrm{NO}$ mixture (see Results) is, within experimental error, equal to the quantum yield of ethane obtained in the $\mathrm{CH}_{4}-i-\mathrm{C}_{4} \mathrm{H}_{10}$ experiments (table 1) indicates that it is nearly exclusively formed as the neutral product of reaction 6 and, to a much lesser extent, reaction 7 . The isotopic composition of the hydrogen in the $\mathrm{CH}_{4}-\mathrm{CD}_{4}$ experiment is actually reasonably consistent with that predicted on the basis of $\mathrm{CH}_{3}^{+}\left(\mathrm{CD}_{3}^{+}\right)$reacting with $\mathrm{CH}_{4}\left(\mathrm{CD}_{4}\right)$. At least, the observed value of 1.1 for the product ratio $\mathrm{D}_{2} / \mathrm{HD}$ is close to the predicted value of $1.13-1.25$ [26]. Apparently, $\mathrm{H}$-atoms which are formed via the unimolecular dissociation of the $\mathrm{CH}_{4}^{+}$ion (reaction 3) and possibly also by neutralization mechanisms are scavenged by NO. However, the low value of $\Phi\left(\mathrm{H}_{2}\right)$ and $\Phi(\mathrm{HD})$ (see Results) obtained in the photolysis of a $\mathrm{CH}_{4}-i-\mathrm{C}_{4} \mathrm{D}_{10}$ mixture in the absence of $\mathrm{NO}$ indicates that a considerable fraction of the $\mathrm{H}$-atoms disappear from the system by reaction on the wall and by addition to olefinic products. It is therefore not surprising that there is good agreement between the quantum yields of hydrogen obtained here and the value reported previously by Jensen and Libby [2]. On the other hand, the much higher value $(\sim 5)$ obtained in the windowless apparatus of Walker and Back [1] may be explainable by a number of factors, including the differences in neutralization mechanism mentioned in the previous section, or perhaps to experimental difficulties in analyzing the $\mathrm{H}_{2}$ product in the presence of excess helium.

\section{d. Superexcited Methane}

A comparison of the quantum yields of the products obtained in the photolysis of pure $\mathrm{CH}_{4}$ with the neon and helium resonance lamps (tables 1 and 2) shows that there are actually no significant differences. This is not surprising in view of the fact that the helium and neon resonance photoelectron spectra and mass spectral cracking patterns are very similar. This is also indicated by the fact that the primary ion abundances $\left(\mathrm{CH}_{4}^{+}, \mathrm{CH}_{3}^{+}, \mathrm{CH}_{2}^{+}\right)$are about the same in the $\mathrm{He}^{*}$ and $\mathrm{Ne}^{*}$ Penning ionization of $\mathrm{CH}_{4}$ [27]. More importantly, because the ionization quantum yield is close to unity both at the neon and helium resonance line [10-11] the contribution of superexcited $\mathrm{CH}_{4}$ fragmentation, which would introduce new intermediates $\left(\mathrm{C}, \mathrm{CH}, \mathrm{CH}_{2}\right)$ to the system [22], is minor over the entire wavelength region [28]. A striking confirmation of this view follows from a recent far ultraviolet study of $\mathrm{CH}_{4}$ by Welch and Judge [29] in which no emission due to excited $\mathrm{CH}$ or $\mathrm{CH}_{2}$ species could be observed over the range 62 to $77 \mathrm{~nm}$. Emission was however seen at shorter and higher wavelengths. It is however of interest that the consistent values of $\Phi\left(\mathrm{C}_{2} \mathrm{H}_{2}\right)$ obtained in the $58.4 \mathrm{~nm}$ photolysis of $\mathrm{CH}_{4}-i-\mathrm{C}_{4} \mathrm{H}_{10}$ mixtures can be attributed to $\mathrm{C}\left({ }^{1} \mathrm{~S}\right)$ or $\mathrm{C}\left({ }^{1} \mathrm{D}\right)$ atoms formed by the fragmentation of superexcited methane molecules

$$
\mathrm{CH}_{4}+h \nu \rightarrow \mathrm{C}+\mathrm{H}_{2}+\mathrm{H}_{2}(\text { or } 2 \mathrm{H})
$$

followed by the insertion mechanism [30]

$$
\mathrm{C}+\mathrm{CH}_{4} \rightarrow \mathrm{C}_{2} \mathrm{H}_{2}+\mathrm{H}_{2} \text {. }
$$




\begin{tabular}{|c|c|c|c|c|c|c|c|c|c|}
\hline $\mathrm{CH}_{4}$ & $\mathrm{O}_{2}$ & Additive & \multirow{2}{*}{$\begin{array}{l}\text { Photons } \\
\text { absorbed } \\
\times 10^{-15}\end{array}$} & $\mathrm{C}_{2} \mathrm{H}_{2}$ & $\mathrm{C}_{2} \mathrm{H}_{4}$ & $\mathrm{C}_{2} \mathrm{H}_{6}$ & $\mathrm{C}_{3} \mathrm{H}_{6}$ & $\mathrm{C}_{3} \mathrm{H}_{8}$ & $n-\mathrm{C}_{4} \mathrm{H}_{10}$ \\
\hline \multicolumn{3}{|c|}{ Pressure (Torr) } & & \multicolumn{6}{|c|}{ Quantum yields } \\
\hline 4.8 & & & 5 & 0.005 & 0.43 & 0.25 & 0.007 & 0.036 & \\
\hline 4.8 & & & 10 & .006 & .40 & .31 & .017 & .075 & 0.007 \\
\hline 4.8 & & & 20 & .006 & .39 & .34 & .011 & .10 & \\
\hline 4.8 & & & 29 & .006 & .35 & .38 & .013 & .13 & .026 \\
\hline 4.8 & & & 145 & .004 & .15 & .44 & .010 & .18 & .036 \\
\hline 4.8 & 0.05 & & 10 & .002 & .35 & .01 & .006 & .01 & \\
\hline $1.95^{*}$ & & & 60 & & .08 & .0016 & & & \\
\hline $2.0^{*}$ & & & 120 & & .063 & .017 & & & \\
\hline $0.23^{* *}$ & & & & .12 & .32 & .36 & & & \\
\hline 10.5 & & $i-\mathrm{C}_{4} \mathrm{H}_{10}-0.45$ & & .002 & .058 & .75 & .062 & .66 & \\
\hline 5.4 & .05 & $i-\mathrm{C}_{4} \mathrm{H}_{10}-0.05$ & & .002 & .049 & .46 & .043 & .43 & .242 \\
\hline 10.5 & .10 & $i-\mathrm{C}_{4} \mathrm{H}_{10}-0.10$ & & .002 & .046 & .46 & .034 & .42 & .23 \\
\hline 20.5 & .20 & $i-\mathrm{C}_{4} \mathrm{H}_{10^{-}}-0.20$ & & .002 & .029 & .46 & .027 & .43 & .23 \\
\hline 10.5 & .10 & $n-\mathrm{C}_{4} \mathrm{H}_{10}-0.10$ & & .002 & .061 & .518 & .042 & .26 & \\
\hline 10.5 & .10 & $i-\mathrm{C}_{5} \mathrm{H}_{12}-0.10$ & & .002 & .070 & .42 & .017 & .04 & .25 \\
\hline
\end{tabular}

Reaction cell volume: $220 \mathrm{~cm}^{3}$.

* Ref. [2]

** Ref. [1]

TABle 2. Photolysis of $\mathrm{CH}_{4}$ at 74.3-73.6 nm

\begin{tabular}{|c|c|c|c|c|c|c|c|c|c|}
\hline $\mathrm{CH}_{4}$ & $\mathrm{O}_{2}$ & Additive & \multirow{2}{*}{$\begin{array}{c}\text { Photons } \\
\text { absorbed } \\
\times 10^{-15}\end{array}$} & $\mathrm{C}_{2} \mathrm{H}_{2}$ & $\mathrm{C}_{2} \mathrm{H}_{4}$ & $\mathrm{C}_{2} \mathrm{H}_{6}$ & $\mathrm{C}_{3} \mathrm{H}_{6}$ & $\mathrm{C}_{3} \mathrm{H}_{8}$ & $n-\mathrm{C}_{4} \mathrm{H}_{10}$ \\
\hline \multicolumn{3}{|c|}{ Pressure (Torr) } & & \multicolumn{6}{|c|}{ Quantum Yields } \\
\hline 4.9 & & & 5 & 0.001 & 0.43 & 0.24 & 0.0021 & 0.024 & \\
\hline 4.9 & & & 20 & .001 & .41 & .27 & .008 & .060 & \\
\hline 4.9 & & & 40 & .002 & .29 & .27 & .008 & .072 & 0.015 \\
\hline 4.9 & & & 120 & .001 & .22 & .30 & .009 & .090 & .015 \\
\hline 10 & & & 15 & $\sim .0006$ & .39 & .28 & .006 & .057 & \\
\hline 10 & 0.2 & & 15 & $\sim .0006$ & .33 & .010 & .007 & .018 & \\
\hline 10 & 0.2 & Acetone-0.1 & 15 & $\leqslant .0001$ & .44 & .003 & .003 & .001 & \\
\hline 10 & 0.2 & $i-\mathrm{C}_{4} \mathrm{H}_{10}-0.1$ & & $\leqslant .0001$ & .03 & .46 & .03 & .443 & .213 \\
\hline 10 & 0.2 & $\mathrm{C}_{3} \mathrm{H}_{x^{-}-0.2}$ & & $\leqslant .0001$ & .03 & .75 & .20 & & \\
\hline
\end{tabular}

The near absence of $\mathrm{C}_{2} \mathrm{H}_{2}$ as a product in the corresponding neon resonance experiments is tentatively ascribed to the fact that in this wavelength region neutral excited $\mathrm{CH}_{4}$ molecules are produced with a quantum yield very close to zero as compared to $\sim 0.05$ at $58.4 \mathrm{~nm}[11]$.

\subsection{Ion-Molecule Reactions}

The photolysis of methane with helium or neon resonance radiation is an ideal method for the study of reactions of $\mathrm{CH}_{5}^{+}$and $\mathrm{C}_{2} \mathrm{H}_{5}^{+}$ions. This is so because of the relative simplicity of the primary ion spectrum $\left(\mathrm{CH}_{4}^{+}\right.$and $\mathrm{CH}_{3}^{+}$account for 95 percent of the primary ions), and because of the negligible contribution of reactive free radical species $\left(\mathrm{C}, \mathrm{CH}, \mathrm{CH}_{2}\right)$ which would be present if the dissociative processes of super- excited methane molecules had to be considered. Although of some intrinsic interest, the results which will be discussed here serve more as an illustration of the type of information about ion-molecule reaction kinetics which can be gained from this type of experiment.

\section{a. Reactions of the Ethyl Cation}

As already indicated earlier in the Discussion, the ethane product observed in the photolysis of $\mathrm{CH}_{4}-i$ $\mathrm{C}_{4} \mathrm{H}_{10}-\mathrm{O}_{2}$ mixtures is nearly all (except for a minor contribution from a reaction of the $\mathrm{C}_{2} \mathrm{H}_{4}{ }^{+}$ion) formed by the transfer of a hydride ion to $\mathrm{C}_{2} \mathrm{H}_{5}{ }^{+}$from the isobutane. Taking advantage of this fact, a number of deuterium labeling experiments have been carried out in order to assess the mechanistic details of the 
hydride transfer reactions between the ethyl ion and a number of hydrocarbon molecules. Table 3 summarizes the experimental observations relating to these questions. The relative rate constants given in the last column of table 3 are based on the determination of the $\mathrm{C}_{2} \mathrm{D}_{5} \mathrm{H}\left(\mathrm{C}_{2} \mathrm{H}_{6}\right)$ and $\mathrm{C}_{2} \mathrm{D}_{6}\left(\mathrm{C}_{2} \mathrm{H}_{5} \mathrm{D}\right)$ products formed in the irradiation of $\mathrm{CD}_{4}\left(\mathrm{CH}_{4}\right)$ in the presence of about 5 percent partially deuterated hydrocarbon, and with $\mathrm{O}_{2}$ present as a radical scavenger (see Results).

TABLE 3. $\mathrm{H}^{-}$and $\mathrm{D}^{-}$transfer to the ethyl cation

\begin{tabular}{l|l|l|c}
\hline \multirow{2}{*}{\begin{tabular}{c}
\multirow{2}{*}{$\mathrm{nm}$} \\
\end{tabular}} & \multicolumn{2}{|c|}{ Reactants } & \multirow{2}{*}{$k\left(H^{-}\right) / k\left(D^{-}\right)$} \\
\cline { 2 - 3 } & \multicolumn{1}{|c|}{ Ion } & \multicolumn{1}{|c}{ Molecule } & \\
\hline $74.4-73.6$ & $\mathrm{C}_{2} \mathrm{D}_{5}^{+}$ & $c-\mathrm{C}_{6} \mathrm{H}_{6} \mathrm{D}_{6}{ }^{* *}$ & $1.05 \pm 0.05$ \\
58.4 & $\mathrm{C}_{2} \mathrm{D}_{5}^{+}$ & $c-\mathrm{C}_{6} \mathrm{H}_{6} \mathrm{D}_{6}$ & $1.06 \pm 0.05$ \\
58.4 & $\mathrm{C}_{2} \mathrm{H}_{5}^{+}$ & $c-\mathrm{C}_{6} \mathrm{H}_{6} \mathrm{D}_{6}$ & $1.09 \pm 0.05$ \\
$74.4-73.6$ & $\mathrm{C}_{2} \mathrm{D}_{5}^{+}$ & $\mathrm{CD}_{3} \mathrm{CH}_{2} \mathrm{CD}_{3}$ & $0.63 \pm 0.02$ \\
$74.4-73.6$ & $\mathrm{C}_{2} \mathrm{D}_{5}^{+}$ & $\left(\mathrm{CH}_{3}\right)_{3} \mathrm{CD}$ & $6.1 \pm 0.3$ \\
58.4 & $\mathrm{C}_{2} \mathrm{D}_{5}^{+}$ & $\left(\mathrm{CH}_{3}\right)_{3} \mathrm{CD}$ & $6.4 \pm 0.3$ \\
58.4 & $\mathrm{C}_{2} \mathrm{H}_{5}^{+}$ & $\left(\mathrm{CH}_{3}\right)_{3} \mathrm{CD}$ & $6.1 \pm 0.3$ \\
\hline
\end{tabular}

*Total pressure: 20 torr.

${ }^{* *}$ Cyclohexane-1,1,2,2,3,3,- $d_{6}$.

The relative rate data given in the last column of the table indicate that reaction of the $\mathrm{C}_{2} \mathrm{D}_{5}{ }^{+}$ion with the symmetric molecule, cyclohexane-1,1,2,2,3,3- $d_{6}$, shows that there is a slight (5 percent) preference for reaction of an ethyl ion at the $\mathrm{CH}_{2}$ position

$$
\mathrm{C}_{4} \mathrm{D}_{5}^{+}+c-\mathrm{C}_{6} \mathrm{H}_{6} \mathrm{D}_{6} \rightarrow \mathrm{C}_{2} \mathrm{D}_{5} \mathrm{H}+c-\mathrm{C}_{6} \mathrm{H}_{5} \mathrm{D}_{6}^{+}
$$

rather than the $\mathrm{CD}_{2}$ position

$$
\mathrm{C}_{2} \mathrm{D}_{5}^{+}+c-\mathrm{C}_{6} \mathrm{H}_{6} \mathrm{D}_{6} \rightarrow \mathrm{C}_{2} \mathrm{D}_{6}+c-\mathrm{C}_{6} \mathrm{H}_{6} \mathrm{D}_{5}^{+} .
$$

Both reactions are exothermic by $35 \mathrm{kcal} / \mathrm{mol}$ [31]. It is not surprising that the relative importance of reactions 22 and 23 does not change as a function of the energy of the photons used to produce the $\mathrm{C}_{2} \mathrm{D}_{5}^{+}$ ions in $\mathrm{CD}_{4}$. Though the $\mathrm{C}_{2} \mathrm{D}_{5}^{+}$ions may be formed with different energy contents in experiments performed at different energies, in these dilute mixtures any excess energy will be dissipated by unreactive collisions with methane before reaction with the additive can occur. The increase in $k_{22} / k_{23}$ which is seen when $\mathrm{C}_{2} \mathrm{D}_{5}{ }^{+}$is replaced by $\mathrm{C}_{2} \mathrm{H}_{5}^{+}$(table 3 ) is too small to be considered as a genuine isotope effect.

In the reaction of ethyl ions with propane and isobutane, preferential reaction sites are indicated by the ratio $k\left(\mathrm{H}^{-}\right) / k\left(\mathrm{D}^{-}\right)$given in table 3 . In the case of $\mathrm{CD}_{3} \mathrm{CH}_{2} \mathrm{CD}_{3}$, for instance, a value of $0.63 \pm 0.02$ is obtained for transfer of $\mathrm{H}^{-}\left(\Delta H_{r n}=-22.5 \mathrm{kcal} / \mathrm{mol}\right)$ over transfer of $\mathrm{D}^{-}\left(\Delta H_{r n}=-6.5 \mathrm{kcal} / \mathrm{mol}\right)$; this is nearly a factor of two higher than the ratio of $\mathrm{H}$ to $\mathrm{D}$ atoms in the reactant molecule. The value for this ratio obtained here is in reasonable agreement with the somewhat less reliable value of 0.57 derived in an earlier $\mathrm{CD}_{3} \mathrm{CH}_{2} \mathrm{CD}_{3}$ radiolysis study [24] and the value of $0.33 \pm 0.01$ obtained in a tandem mass spectrometer experiment [32].

In the case of $\left(\mathrm{CH}_{3}\right)_{3} \mathrm{CD}$, the ratio $k\left(\mathrm{H}^{-}\right) / k\left(\mathrm{D}^{-}\right)$is 6.1 , independent of wavelength and isotopic labeling of the reactant ion. The statistical value of this ratio is 9.0 ; the fact that the observed value is closer to the statistical value in the case of isobutane than in the case of propane may be explained by the fact that reaction at the primary and tertiary sites in isobutane are both more exothermic $(\Delta H=-8$ and $-38 \mathrm{kcal} / \mathrm{mol}$, respectively) than reaction at the primary and secondary positions in propane $(\Delta H=-6.5$ and -22.5 $\mathrm{kcal} / \mathrm{mol}$, respectively). In addition, steric effects may play a role in these reactions, and there is a possibility that the weaker tertiary bond in isobutane is strengthened by the deuterium labeling. It is interesting to note that $n$-butane is an important product in all $\mathrm{CH}_{4^{-}}$ $i-\mathrm{C}_{4} \mathrm{H}_{10}$ experiments (tables 1 and 2). One of the most obvious routes by which this product may be formed is through the isomerization of the $\left(\mathrm{CH}_{3}\right)_{2}$ $\mathrm{CHCH}_{2}^{+}$ion formed in the hydride transfer reaction:

$$
\begin{array}{r}
\mathrm{C}_{2} \mathrm{H}_{5}{ }^{+}+\left(\mathrm{CH}_{3}\right)_{3} \mathrm{CH} \rightarrow\left(\mathrm{CH}_{3}\right)_{2} \mathrm{CHCH}_{2}^{+}+\mathrm{C}_{2} \mathrm{H}_{6} \\
\Delta H=-38 \mathrm{kcal} / \mathrm{mol}
\end{array}
$$

to the thermodynamically more stable sec-butyl ion:

$$
\left(\mathrm{CH}_{3}\right)_{2} \mathrm{CHCH}_{2}^{+} \rightarrow \text { sec- } \mathrm{C}_{4} \mathrm{H}_{9}^{+} \quad \Delta H=-16 \mathrm{kcal} / \mathrm{mol}
$$

Such a mechanism is strikingly demonstrated by the observation that 95 percent of the $n$-butane observed in the photoionization of $\mathrm{CH}_{4}-\left(\mathrm{CH}_{3}\right)_{3} \mathrm{CD}-\mathrm{O}_{2}$ mixtures consists of $n-\mathrm{C}_{4} \mathrm{H}_{8} \mathrm{D}_{2}$. Stable sec- $\mathrm{C}_{4} \mathrm{H}_{8} \mathrm{D}^{+}$ions formed in the isomerization are indeed expected to react with $\left(\mathrm{CH}_{3}\right)_{3} \mathrm{CD}$ exclusively by the exothermic reaction channel:

$$
\begin{array}{r}
\text { sec- } \mathrm{C}_{4} \mathrm{H}_{8} \mathrm{D}^{+}+\left(\mathrm{CH}_{3}\right)_{3} \mathrm{CD} \rightarrow n-\mathrm{C}_{4} \mathrm{H}_{8} \mathrm{D}_{2}+\left(\mathrm{CH}_{3}\right)_{3} \mathrm{C}^{+} \\
\Delta H=-11.5 \mathrm{kcal} / \mathrm{mol} .
\end{array}
$$

Apparently a fraction of the isobutyl ions formed in reaction 24 isomerize to the $t-\mathrm{C}_{4} \mathrm{H}_{9}^{+}$structure rather than to the sec- $\mathrm{C}_{4} \mathrm{H}_{9}^{+}$structure, since the yield of $n$-butane is lower than that which would be predicted from the fact that about 85 percent of the ethyl ions are expected to undergo reaction 24 .

\section{b. Reactions of $\mathrm{CH}_{5}{ }^{+}$}

In the 58.4 or $73.5-74.6 \mathrm{~nm}$ irradiation of pure $\mathrm{CH}_{4}$ no neutral product can be unambiguously ascribed to the presence of $\mathrm{CH}_{4}^{+}$, and therefore of $\mathrm{CH}_{5}^{+}$, even though the latter ion must account for approximately 50 percent of the primary ion spectrum. The latter estimate is based on the fact that the only other major ion, $\mathrm{CH}_{3}^{+}$, has been shown to yield $\mathrm{C}_{2} \mathrm{H}_{4}$ with a quantum yield of $0.43 \pm 0.06$. Addition of higher alkanes to 
$\mathrm{CH}_{4}$ does however reveal the presence of $\mathrm{CH}_{5}^{+}$, and does also provide some information concerning the proton transfer reaction

$$
\mathrm{CH}_{5}^{+}+\mathrm{C}_{n} \mathrm{H}_{2 n+2} \rightarrow \mathrm{CH}_{4}+\left[\mathrm{C}_{n} \mathrm{H}_{2 n+3}\right]^{*} .
$$

In $\mathrm{CH}_{4}-i-\mathrm{C}_{4} \mathrm{H}_{10}$ mixtures (tables 1 and 2$), \Phi\left(\mathrm{C}_{3} \mathrm{H}_{8}\right)$ represents a minimum value of $\Phi\left(\mathrm{CH}_{5}^{+}\right)$. Isotopic labeling experiments in this and previous radiolysis and mass spectrometric studies have shown that the now well established reaction sequence

$$
\begin{aligned}
& \mathrm{CH}_{5}^{+}+\left(\mathrm{CH}_{3}\right)_{3} \mathrm{CH} \rightarrow 2 \mathrm{CH}_{4}+\text { sec- } \mathrm{C}_{3} \mathrm{H}_{7}^{+} \\
& \mathrm{C}_{3} \mathrm{H}_{7}^{+}+\left(\mathrm{CH}_{3}\right)_{3} \mathrm{CH} \rightarrow \mathrm{C}_{3} \mathrm{H}_{8}+\left(\mathrm{CH}_{3}\right)_{3} \mathrm{C}^{+}
\end{aligned}
$$

adequately accounts for the formation of $\mathrm{C}_{3} \mathrm{H}_{8}$. In addition, however, the following competing reaction channel must be considered:

$$
\mathrm{CH}_{5}^{+}+\left(\mathrm{CH}_{3}\right)_{3} \mathrm{CH} \rightarrow \mathrm{CH}_{4}+\mathrm{H}_{2}+\mathrm{C}_{4} \mathrm{H}_{9}^{+}
$$

where $\mathrm{C}_{4} \mathrm{H}_{9}^{+}$may be $i-\mathrm{C}_{4} \mathrm{H}_{9}^{+}$or $t-\mathrm{C}_{4} \mathrm{H}_{9}^{+}$. The fact that $\Phi\left(\mathrm{C}_{2} \mathrm{H}_{6}+\mathrm{C}_{3} \mathrm{H}_{8}\right)$ in the $\mathrm{CH}_{4}-i-\mathrm{C}_{4} \mathrm{H}_{10} \mathrm{O}_{2}$ experiments does not add up to unity attests to the occurence of reaction 30 . On the same grounds the lower value for $\Phi\left(\mathrm{C}_{3} \mathrm{H}_{8}\right)$ observed in the $\mathrm{CH}_{4}-n-\mathrm{C}_{4} \mathrm{H}_{10}$ experiment given in table 1 points to a relatively larger contribution of a dissociative proton transfer reaction analogous to 30 in agreement with mass spectrometric observations. The relatively high yield of $n-\mathrm{C}_{4} \mathrm{H}_{10}$ in the $\mathrm{CH}_{4}-i$ $\mathrm{C}_{5} \mathrm{H}_{12}$ experiment (table 1) must be accounted for by preferential transfer of a proton to a $\mathrm{CH}_{3}$ group to give sec- $\mathrm{C}_{4} \mathrm{H}_{9}^{+}$

$$
\mathrm{CH}_{5}^{+}+\left(\mathrm{CH}_{3}\right)_{2} \mathrm{CHCH}_{2} \mathrm{CH}_{3} \rightarrow 2 \mathrm{CH}_{4}+\text { sec- } \mathrm{C}_{4} \mathrm{H}_{9}^{+} \text {. }
$$

The smaller yield propane observed in the same experiment can be ascribed to proton transfer to $\mathrm{CH}_{2}$ group.

\section{References and Note}

[la] Back, R. A., and Walker, D. C., J. Chem. Phys. 37, 2348 (1962).

[lb] Walker, D. C., and Back, R. A., Ibid. 38, 1526 (1963).

[2] Jensen, C. A., and Libby, W. F., Ibid. 49,2831 (1968).

[3] Rebbert, R. E., and Ausloos, P., J. Am. Chem. Soc. 90, 7370 (1968).

[4a] Lias, S. G., Rebbert, R. E., and Ausloos, P., J. Chem. Phys. 52, 773 (1970).

[4b] Re' bert, R. E., Lias, S. G., and Ausloos, P., J. Res. Nat. Bur. tand. (U.S.), 75A, (Phys. and Chem.) No. 6, 607-612 (1972).

[5a] Tellinghuisen, J. B., Winkler, C. A., Bennett, S. W., and Phillips, L. F., J. Phys. Chem. 75, 3499 (1971). [5b] Tellinghuisen, J. B., Winkler, C. A., and Phillips, L. F., Ibid. 76, 298 (1972).

[6] Wauchop, T. S., and Broida, H. P., J. Geophys. Res. 76, 21 (1971).

[7] Gorden, R., Jr., Rebbert, R. E., and Ausloos, P., Nat. Bur. Stand. (U.S.), Tech. Note 496, 34 pages (1969).

[8] Cerrtain commercial equipment, instruments, or materials are identified in this paper in order to adequately specify the experimental procedure. In no case does such identification imply recommendation or endorsement by the National Bureau of Standards, nor does it imply that the material or equipment identified is necessarily the best available for the purpose.

[9] Kinsinger, J. A., Stebbings, W. L., Valenzi, R. A., and Taylor, J. W., Anal. Chem. 44, 773 (1972).

[10] Bennett, S. W., Tellinghuisen, J. B., and Phillips, L. F., J. Chem. Phys. 75, 719 (1971).

[11] Rebbert, R. E., and Ausloos, P., J. Res. Nat. Bur. Stand. (U.S.), 75A (Phys. and Chem.), No. 5, 481-485 (1971).

[12] Sieck, L. W., and Gordon, R. Jr., Chem. Phys. Lett., in press.

[13a] Dibeler, V. H., Krauss, M., Reese, R. M., and Harllee, F. N., J. Chem. Phys. 42,3791 (1965).

[13b] Chupka, W. A., J. Chem. Phys. 48, 2337 (1968).

[14] Turner, D. W., "Molecular Photoelectron Spectroscopy" (Wiley-Interscience, 1970).

[15] Potts, A. W., and Price, W. C., Proc. Roy. Soc. London A326, 165 (1972).

[16] Futrell, J. H. and Tiernan, T. O., Chapter 4 in Fundamental Processes in Radiation Chemistry (Interscience Publ. New York, 1968).

[17] Ausloos, P., Lias, S. G., and Gorden, R., Jr., J. Chem. Phys. 39, 3341 (1963).

[18] Haynes, R. M., and Kebarle, P., J. Chem. Phys. 45, 3899 (1966).

[19a] Munson, M. S. B., and Field, F. H., J. Am. Chem. Soc. 87,3294. (1965).

[19b] Ibid. 87, 4242 (1965).

[20] Ausloos, P., Gorden, R., Jr. and Lias, S. G., J. Chem. Phys. 40, 1854 (1964).

[21] Bosnali, M. W., and Perner, D., Z. Naturforsch 26a, 1768 (1971).

[22] Rebbert, R., and Ausloos, P., J. of Photochemistry 1, 171 (1972/73).

[23] Rebbert R. E., and Ausloos, P., J: Res. Nat. Bur. Stand. (U.S.), 77A, (Phys. and Chem.) No. 1, 109-114 (Jan.-Feb. 1973).

[24] Ausloos, P., Lias, S. G., and Sandoval, I. B., Disc. Faraday Soc. 36,66 (1963).

[25] Sieck, L. W., and Searles, S. K., J. Am. Chem. Soc. 92, 2937 (1970).

[26] Ausloos, P. J., and Lias, S. G., J. Chem. Phys. 38, 2207 (1963).

[27] Cermak, V., and Herman, Z., Coll. Czek. Chem. Commun. 30, 169 (1965).

[28] Ausloos, P., Molec. Photochem. 4, 39 (1972).

[29] Welch, A. R., and Judge, D. L., J. Chem. Phys. 5 7, 286 (1972).

[30a] Braun, W., Bass, A. M., Davis, D. D., and Simons, J. P., Proc. Roy. Soc. 312 A, 417 (1969).

[30b] Husain, D., and Kirsch, L. J., Trans Faraday Soc. 67, 2025 (1971).

[31] Thermochemical values are mainly derived from: Franklin, J. L., Dillard, J. G., Rosenstock, H. M., Herron, J. T., Draxl, K., and Field, F. H., Nat. Bur. Stand. (U.S.), Nat. Stand. Ref. Data Ser. 26, (1969).

[32] Bone, L. I., and Futrell, J. H., J. Chem. Phys. 46, 4084 (1967).

(Paper 77A1-755) 